\title{
The Use of the Median Raphe of Gastrocnemius to Augment the Repair of Achilles Tendon Rupture
}

\author{
Abdullah Ali Al-Zahrany \\ Department of Orthopedics, Taif University, Saudi Arabia
}

\begin{abstract}
Background and Objectives:

Rupture of the Achilles tendon is a common injury among athletes and even sedentary individuals. Presence of a gap between the two ends of the disrupted tendon makes the treatment difficult, however, augmented repair techniques are used in defective Achilles tendon ruptures and provide excellent functional results in active individuals, but it carries an incidence of wound complications like tendon adhesion to the skin. In this study we present an augmentation technique for Achilles tendon rupture that would prevent tendon adhesion to the skin.
\end{abstract}

Material and methods: This prospective study was conducted in King Abdul-Aziz Specialist Hospital, Taif, Saudi Arabia from March 2009 to March 2011 on 12 male patients with defective Achilles tendon ruptures. We used an apponeurotic strip from the median raphe of gastrocnemius, and twisted 180 degrees on itself from medial sides, to allow its smooth external surface to lie next to the skin and cover the rupture site, and the plantaris tendon was incorporated in the repair site.

Results: Twelve male patients with a mean age of 37 years (27-55) were diagnosed as having a ruptured Achilles tendon. Ten patients had been injured during sports activities the other two cases occurred during walking. The mean duration of ruptures before surgery was (20 days) ranging from 3 to 40 days. The mean follow up was 22 months (11- 35) There were no re-ruptures. Three patients had skin necrosis and managed by debridement followed by secondary sutures and satisfactory healing was achieved. There were no tendon adhesion to the skin and the skin over the tendon was movable. All patients returned to their activity after 6- 14 months (mean 8 months).

Conclusion: augmented operative repair of Achilles tendon ruptures is a reliable treatment method for active patients and the repair is preferred to prevent tendon adhesion to the skin. Key words: Gastrocnemius, Repair of Achilles Tendon Rupture

\section{Introduction:}

Most of the ruptures of the Achilles tendon are sport related specially in males who are active intermittently "weekend warriors" and it is usually a disabling condition which is difficult to treat if there is a gap between the two disrupted tendons ends (Maffulli et al, 2011). A relatively hypovascular area exists approximately 
2-6 $\mathrm{cm}$ above the insertion into the calcaneus and this hypovascularity has been implicated in disorders of the tendon and it may predispose the tendon to rupture (Kader et al, 2002). Controversy exists between conservative and surgical treatment in the management of the Achilles tendon rupture for the first time, however, there are distinct benefits and risks for each approach (Chalmers, 2000 and Khan et al, 2005). Surgical repair of Achilles tendon ruptures have lower re-rupture rates, increased postoperative muscle strength, power, endurance, and an earlier return to activities compared with non-operative treatment (Khan et al, 2005). Surgical techniques include augmentation with local flaps, local tendon transfers or synthetic material (Azar, 2003). Surgery is associated with complications as; skin necrosis, delayed wound healing, infection, and tendon adhesion to the skin; however, this latter complication can be minimized or prevented if the augmentation technique is used (Pajala et al, 2009). The aim of this study is to prevent the Achilles tendon adhesion to the skin by using the median raphe of gastrocnemius as an augmentation technique for the repair of Achilles tendon rupture.

Materials and methods: This prospective study was conducted in King Abdul-Aziz Specialist Hospital, Taif, Saudi Arabia from March 2009 to March 2011 on 12 male patients with defective
Achilles tendon ruptures. Diagnoses were done by examining the entire length of the gastrocnemius-soleus and Achilles complex, noting any tenderness, swelling, ecchymosis, and tendon defects or a palpable gap. Hyperdorsiflexion sign is usually found in addition to positive Thompson test and O'Brien needle test (O'Brien, 1984). The surgical techniques used (Karakurt et al, 2006), were done under general or spinal anesthesia, while the patient in prone position a tourniquet was applied and a postero-medial longitudinal incision was made from the calcaneus to the middle of the calf and the incision was deepened through the skin, subcutaneous tissues, and tendon sheath. The ends of the tendon were exposed to excise the ragged ends in fresh ruptures and the scar tissues in old cases. A flap from the median raphe of gastrocnemius of $8 \mathrm{~cm}$ long and $2 \mathrm{~cm}$ wide, was elevated proximally and its upper end was freed and reflected distally keeping its distal end attached to the tendon at a site $1 \mathrm{~cm}$ proximal to the rupture medially and $2 \mathrm{~cm}$ proximal to the rupture laterally. The ruptured ends of the tendon were approximated with number 2 non-absorbable tension suture and a running epitendinous absorbable 2/0 suture using a modified Kessler stitch. The flap was sutured to the distal and proximal stumps with nonabsorbable sutures (figure 1) after twisting it from medial side 180 degrees and allowing its smooth external surface 
to lie next to the skin and covers the rupture site. After proximal release of the plantaris tendon it was incorporated in the repair site by passing it from the proximal and distal stumps circumferentially to be sutured with the proximal stump at superomedial corner. The defect between gastrocnemius aponeurosis was repaired with $3 / 0$ nonabsorbable sutures and the paratenon, deep fascia and subcutaneous tissue were closed with $3 / 0$ absorbable sutures. The skin was closed with $3 / 0$ non-absorbable sutures. A long leg cast was applied with flexion of knee and ankle (30 and 20 degrees respectively) to be removed with the sutures after 2 weeks. A new cast was applied in same position for 2 to 4 weeks to be followed by a below-knee walking cast with the ankle in neutral position for an additional 4 weeks and full weight bearing was given. After extraction of the cast; active range of ankle motion was started and the patients were allowed to wear shoes with high heels for a period of 3 months.
Results: Twelve male patients with a mean age of 37 years (27-55) were diagnosed as having a ruptured Achilles tendon. Ten patients $(83.3 \%)$ had been injured during sports activities the other two cases (16.7\%) occurred during walking. The mean duration of rupture before surgery was (20 days) ranging from 3 to 40 days. The mean follow up was 22 months (11- 35) and there were no re-rupture. Three patients $(25 \%)$ had minimal skin necrosis and managed by debridement followed by secondary sutures where satisfactory healing was achieved and there were no other skin problem. There were no tendon adhesion to the skin and the skin over the tendon was movable. All patients returned to their activity after 6- 14 months (mean 8 months). The mean calf circumferences were $5 \mathrm{~mm}$ (1 to 11) less than the uninjured side. Active range of motion on the affected side was found to be reduced in tow cases (16.7\%) with slight limitation of dorsiflexion. All of the patients were satisfied with the operation. 

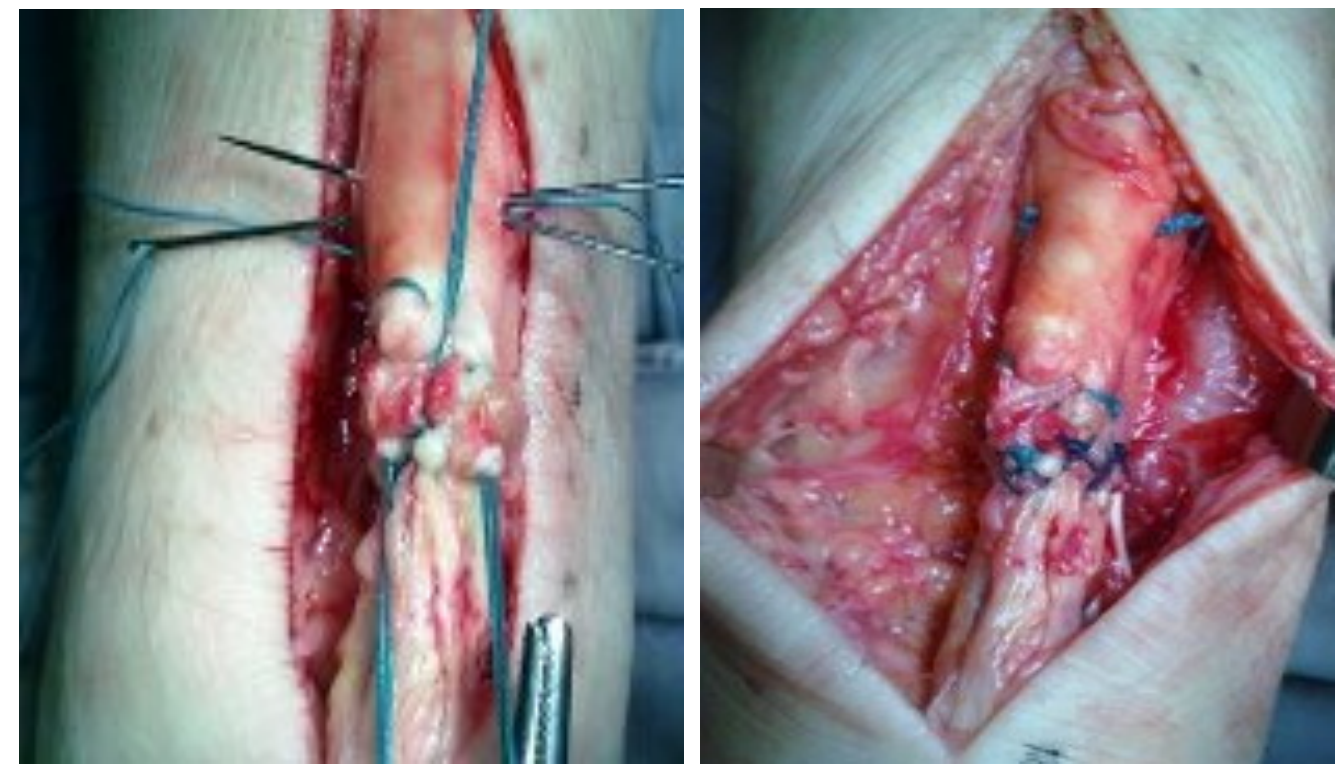

Figure 1: The augmentation flap during and after suturing around the repaired tendon

\section{Discussion:}

Ruptures of Achilles tendon commonly occur in otherwise healthy men between the ages of 30 and 50 years who are active intermittently "weekend warriors" (Maffulli et al, 2011). In this study the 12 injuries occurred in healthy men with age range 27-55 years (mean 37 years) who have had no previous injury or problem reported in the affected leg. Most Achilles tendon tears occur in the watershed zone, approximately $2-6 \mathrm{~cm}$ above the calcaneal insertion of the tendon (Schepsis et al, 2002). Controversy exists regarding conservative management and surgical reconstruction of the ruptured tendon; however, there are distinct benefits and risks for each approach (Cetti et al, 1993, Chalmers 2000 and Kahn et al 2005). In non surgically treated patients, re-rupture rate is approximately 3 times higher than those treated surgically; however, there was a consistent finding of an approximately 33\% higher rate of complications (other than rerupture) in the surgically treated group as; skin necrosis, delayed wound healing, infection, and tendon adhesion to the skin, the latter complication is especially seen after primary end to end repair techniques (Inglis and Sculco 1981, Aldam 1989 and Leitner et al, 1992); however, this latter complication can be minimized or prevented if the augmentation technique is used (Khan et al 2005). It was reported that augmentation adds collagen to the repair site and gives more biomechanical stability to the repair (Mohamed et al 1995 and Azar, 2003). Different surgical techniques were defined for prevention of tendon adhesion; in the study of Cetti et al 1993 they compared the mobile cast group (which allows the ankle motion in early postoperative period) and rigid cast group where they reported adhesion rate of $3.3 \%$ in mobile cast group 
and $13.3 \%$ in rigid cast group and they concluded that prolonged immobilization allows the formation of scar tissue bridges to the surrounding tissue resulting in a decreased tendon mobility. Aldam, (1989) made a 3 to $4 \mathrm{~cm}$ transverse incision in the skin just distal to the palpable gap in the tendon and adhesion between the skin and the tendon are avoided because they lie at different levels after the operation. Esemenli et al, (1996) used a new open surgical repair technique in three cases without opening the rupture site and none of them had tendon adhesion to the skin.

However some principles are important for prevention of tendon adhesion in open surgical methods; making paramedian (posterolateral or posteromedial) incision (Boyden et al 1996), making incision away from the rupture site (Babu et al 1994), closing the paratenon and deep fascia (Nestorson et al 2000), Closing the rupture site with flap and make a smooth surface in repair area (Boyden et al 1996) and Early postoperative ankle motion (Leitner et al 1992). In the present study we used posteromedial longitudinal incision with closure of paratenon and deep fascia. In the present study the flap technique used was a combination of classical median gastrocnemius aponeurosis flap turned down for augmentation of repair (Mohamed et al 1995) and Lindholm's two flaps techniques (Boyden et al 1996). In classical flap, rough surface lies next to the skin and tendon adhesion to the skin may be expected but if combined with Lindholm's technique the smooth surface lies next to the skin preventing this adhesion (Karakurt et al, 2006). In the present study there were no tendon adhesion to the skin and the skin over the tendon was movable, which is comparable to the results reported in the literature (Pajala et al, 2009). The result of our study showed that there were no rerupture. According to Karakurt et al, (2006), this combination technique is stronger than Lindholm's technique, because one large flap was used and the repair was augmented with plantaris tendon in addition to that the technique can be used easily by any Orthopaedic surgeon. Three patients (25\%) had minimal skin necrosis which was higher than reported in the literature (Pajala et al, 2009), however, this may be related to small number of patients in the study. All patients returned to their activity after 6- 14 months (mean 8 months), all of them were able to do a single-toe rise and all of the patients were satisfied with the operation. These results are comparable to that reported by Karakurt et al, (2006).

Conclusion: augmented operative repair of Achilles tendon ruptures is a reliable treatment method for active patients and the repair is preferred to prevent tendon adhesion to the skin.

\section{REFERENCES}

1. Aldam CH, (1989). Repair of calcaneal tendon ruptures. A safe technique. J Bone Joint Surg (Am); 71: 486-488.

2. Azar FM, (2003). Traumatic Disorders. In: Canale ST. Ed. Campbell's Operative Orthopaedics. 10th ed. Mosby Company: 2449-2493. 
3. Babu NV, Chittaranjan S, Abraham G, et al, (1994). Vascularized extansor digitorum brevis to reconstruct the Achilles tendon: A case report. Acta Orthop Scand; 65: 101-102.

4. Boyden EM, Kitaoka HB, Cahalan TD, et al, (1996). Late versus early repair of Achilles tendon rupture: Clinical and biomechanical evaluation. Adv Orthop Surg; 20: 114-116.

5. Cetti R, Christensen SE, Ejsted R, Jensen NM, Jorgensen U, (1993). Operative versus non-operative treatment of Achilles tendon rupture. A prospective randomized study and review of the literature. Am J Sports Med. Nov-Dec;21 (6):791-9.

6. Chalmers J, (2000). Review article: Treatment of Achilles tendon ruptures. J Orthop Surg (Hong Kong); 8(1):97-99.

7. Esemenli BT, Gündeş H, Mecikoğlu M, (1996). A method for combined percutaneous and open surgical repair of Achilles tendon ruptures: A report of three cases. Foot Ankle Int; 17: 217-220.

8. Inglis AE and Sculco TP, (1981). Surgical repair of ruptures of the tendo Achilles. Clin Orthop; 156: 160-169.

9. Kader D, Saxena A, Movin T, Maffulli N, (2002). Achilles tendinopathy: some aspects of basic science and clinical management. $\mathrm{Br} \mathrm{J}$ Sports Med. Aug; 36(4):239-49.

10. Karakurt L, Belhan O, Yilmaz $\mathbf{E}$ and Varol T, (2006). Augmented Repair of Achilles Tendon Ruptures. Firat Tip Dergisi; 11(4): 197-200.

11. Khan RJ, Fick D, Keogh A, et al, (2005). Treatment of acute Achilles tendon ruptures. A meta-analysis of randomized, controlled trials. J Bone Joint Surg Am; 87(10):2202-10.

12. Leitner A, Voigt Ch, Rahmanzadeh $\mathbf{R}$, (1992). Treatment of extensive aseptic defects in old Achilles tendon ruptures: Methods and case reports. Foot Ankle Int; 13: 176-180.

13. Maffulli N, Longo UG, Maffulli GD, Khanna A, Denaro V, (2011). Achilles tendon ruptures in elite athletes. Foot Ankle Int; 32(1):9-15.

14. Mohamed A, Rahamatalla A, Wynne-Jones CH, (1995). Tissue expansion in late repair of tendo Achilles rupture. J Bone Joint Surg (Br), 77: 64-66.

15. Nestorson J, Movin T, Möller M, et al, (2000). Function after Achilles tendon rupture in elderly. Acta Orthop Scand; 71: 64-68. 22. 22.

16. Nistor L, (1981). Surgical and nonsurgical treatment of Achilles tendon ruptures. J Bone Joint Surg (Am); 63: 394-399.

17. O'Brien T, (1984). The needle test for complete rupture of the Achilles tendon. J Bone Joint Surg Am.;66 (7):1099-101.

18. Pajala A, Kangas J, Siira P, Ohtonen P, Leppilahti J, (2009). Augmented compared with nonaugmented surgical repair of a fresh total Achilles tendon rupture. A prospective randomized study. J Bone Joint Surg Am; 91(5):1092-100.

19. Schepsis AA, Jones H, Haas AL, (2002). Achilles tendon disorders in athletes. Am J Sports Med; 30(2):287-305. 


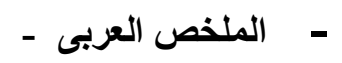

استعمال الرفاء المتوسط من عضلة الساق الخلقية لتدعيم إصلاح التمزق - لترب

في وثر أخيل

بحث مقلم من: د/ عبد الله على الزهرانى احئ

قسم جر احة العظام كلية الطب جامعة الطائفــ المملكة العربية السعودية

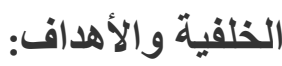

ان تمزق وتر العرقوب هو إصابة شائعة بين الرياضيين، وحتى بين الأفر اد العاديين و وجود فجوة بين طرفي

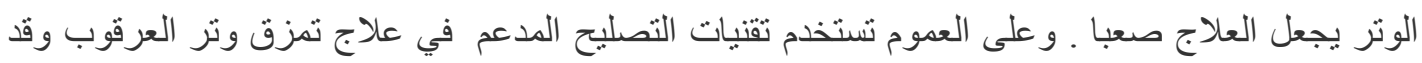

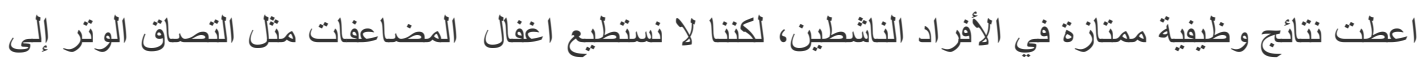
الجلد. في هذه الدراسة نقدم تقنية الاصلاح المدعم لعلاج تمزق وتر العرقوب التي من شأنها منع التصاق الوتر الى الجلد.

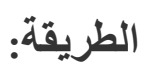

أجريت هذه الدراسة الاستطلاعية في مستشفى الملك عبد العزيز التخصصي، الطائف، المملكة العربية

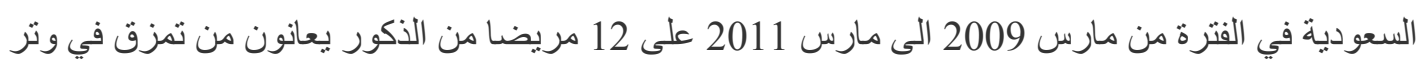

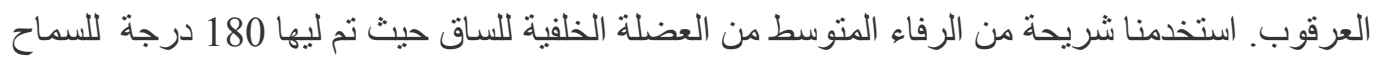
للسطح الخارجي الأملس ليكون تحت الجلد وتغطية موقع التمزق كما استخدم وتر العضلة الأخمصية لتدعيم (الاصلاح.

النتائج:

تم تشخيص وجود تمزق في وتر العرقوب في اثنا عشر مريضا من الذكور مع منوسط عمر 37 سنة (2755)، وقد أصيب عشرة مرضى خلال الأنشطة الرياضية و في حالتين غيرهم و قعت الاصنية أثناء المشي.

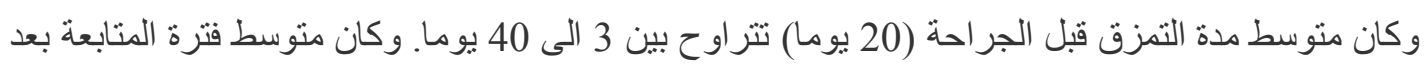

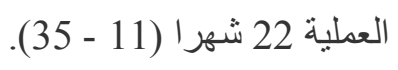

و فى ثلاثة مرضى حدث نخر للجلد و نم علاجهم باستئصسال الاجز اء النخرة وبعد ذلك اغلق الجرح باستخدام

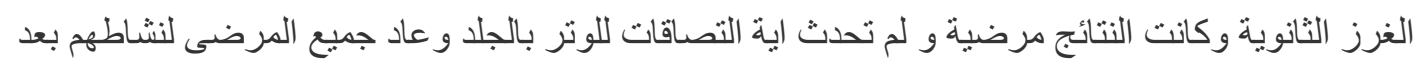

$$
\text { 14-6 شهرا (بمتوسط } 8 \text { أشنهر ). }
$$

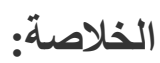

ان الإصلاح المدعم لتمزق وتر العرقوب هو طريقة يفضل الاخذ بها لعلاج المرضى ولمنع التصاق الوتر 